\title{
The experience of pregnant women with HIV: scoping review
}

\author{
A.A. Putri Melastini ${ }^{\mathrm{a}, 1, *}$, Mufdlilah ${ }^{\mathrm{b}, 2}$ \\ a,b Universitas 'Aisyiyah Yogyakarta, Indonesia \\ 1anakagungputry@gmail.com; ${ }^{2}$ mufdlilah.stikes@gmail.com \\ *corresponding author
}

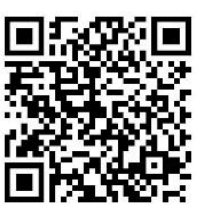

\section{ARTICLE INFO}

Article history

Received, $5^{\text {th }}$ April 202 Revised, $10^{\text {th }}$ May 2021 Accepted, $25^{\text {th }}$ May 2021

Keywords

Experience

Women Pregnancy

with HIV

\begin{abstract}
HIV attacks human immune system and HIV occurrence during pregnancy is four times higher compared to when not pregnant. ANC visit can help early detection and identify if there is complication related to the mother's health and the infant's health. The purpose of this study was the evidence of pregnant women's experience with HIV. Data sources used databses i.e. Pubmed, Wiley, Science Direct, and Google Scholar. There were 714,336 articles from initial hit publised from 2011-2020, and after filtering process 8 articles were included. This scoping review method was adapted from Arksey and O'Malley. There were 3 themes emerged from this study, which were psychology, coping stress, and the role of medical staffs. Studies stated that participants experience lack of comfortable circumstances, not obtaining sufficient attention and experience violence in the household.
\end{abstract}

This is an open access article under the CC-BY-SA license.

\section{Introduction}

HIV lunges and devastates Human Immune System when someone have already infected by this virus. HIV poses as a very complex health problem in life. This case mainly occurs in countries that have medium and low income (Fermin, 2012). The contagion of HIV can happen through various way including: sexual activity without knowing how to safeguard themselves from HIV (Stallard et al., 2016), the occurrence of infection while undertake blood transfusion (Ashaba et al., 2017), needles that are using for drugs consecutively (Abtew et al., 2016), and Pregnant woman can infected the fetus through placenta as well during childbirth until breastfeeding (Bettany-Saltikov, n.d.).

Overall, there are 37, 9 million new patient of HIV in the world. Teenage girls are having two times chance of living with HIV compared to boy and 35\% women have encountered physical abused from their partner (North, 2017). Pregnant women who positive with HIV are very risky compared to non-pregnant woman. Preventive effort need to be enhanced by replicate screening during pregnancy to prevent transmittal on the fetus (Chulach \& GagnonHolmes, 2016). Psychological condition such as worry frequently felt by someone positive with HIV will impact the development of fetus (Ngocho et al., 2019). Confront the uncertainty and fear according to contagion of HIV (Fasoulakis, 2017). Possess a good strategy management can overcome the transmittal HIV to the fetus (Huang et al., 2017). Comprehensive antenatal comply the need of mental health and depression (Fermin, 2012). The importance of visiting antenatal care with professional staff will help for caring and detecting mother's condition during pregnancy. Ensure the condition for preparing referral in case of complication and infection (WHO, 2020). HIV infection on mothers cause disruption on fetus's growth and Mothers with HIV infection during childbirth will have an impact on breast milk, diarrhea, and unbalanced nutrition on the infant (Genevieve, 2018). 
Social problems along with fear are often hidden by them (Holland \& Roger, 2021). The Stigma of HIV among community become wide spread social problem. The minimum of HIV knowledge mainly among the society, pregnant woman infected with HIV will be humiliated and discriminated lead to the decreased health of the mother (Hawker et al., 2002). The importance of emotional support from partner, family, and society is the patient will be respected and cared regardless their race, religion, gender, nationality, or condition (Arksey \& O'Malley, 2019). Knowing and understanding the experiences of pregnant woman infected HIV, will assist for identification their needs and create intervention from mapping the problems which will be found. Therefore, the writer will map the problems of pregnant woman infected HIV to discover the aim of this research in the future.

\section{The Proposed Method}

Grouping and conceiving information about research activities with the theme which will be searched become the purpose of scoping review. The methodology which will be used is from fream work Arksey and O'Malley that already have under development by Leave et al (Hidayanti, 2016). There are 5 steps:

\section{a. Step 1 Identifying the Scoping Review Questions}

The application of PEOS is greatly help in examining the problems that focus on question with inclusion and exclusion criteria. In qualitative research PEOS has important role in identification and good for using it (Hill et al., 2018).

Table 1. Framework Reserch Question PEOS

\begin{tabular}{cccc}
\hline P & E & O & S \\
\hline Women Pregnant & HIV & Experience women of & Qualitative study \\
Antenatal Period & & pregnant with HIV & \\
Prenatal Period & & & \\
\hline
\end{tabular}

\section{b. Step 2 Identifying the Relevant Articles}

Searching on articles is using base data such as PubMed, Wiley, Science Direct and Grey Literature Google Scholar. Screening the keywords which are appointed in order to ease on searching theme is "Pregnant Woman", "Antenatal Period", or "Prenatal Period". The writer makes selection on abstract and title, publication article that is released in the last 10 years, research article or journal that are using Indonesian or English language.

\section{c. Step 3 Selection of Article}

Selecting the articles contain 8 databases from 714336 identification obtain from data base and grey literature, selecting title and abstract obtain 62 . Get 42 exclude articles and 2 articles in selection articles from the last 10 years. Screening by observed the inclusion and exclusion criteria for mapping. Prisms flow help in the process of screening and considering in searching article in a systematic identification, screening, the appropriateness article which will be criticized and included.

The Process of screening data will be done by the reporting item for further systematic observation and Meta-Analysis (PRISMA). Prism is screening the amount of identification note, included and excluded without exclusion reasons. PRISMA is considered as the valid way because it can increase the quality of publication. PRISMA can be seen from graphic. 
8 databases will be criticized by using critical appraisal (Hawker) that is assessing the articles by seeing the result so that the articles can be used. Assessment from (Hawker et al., 2002).

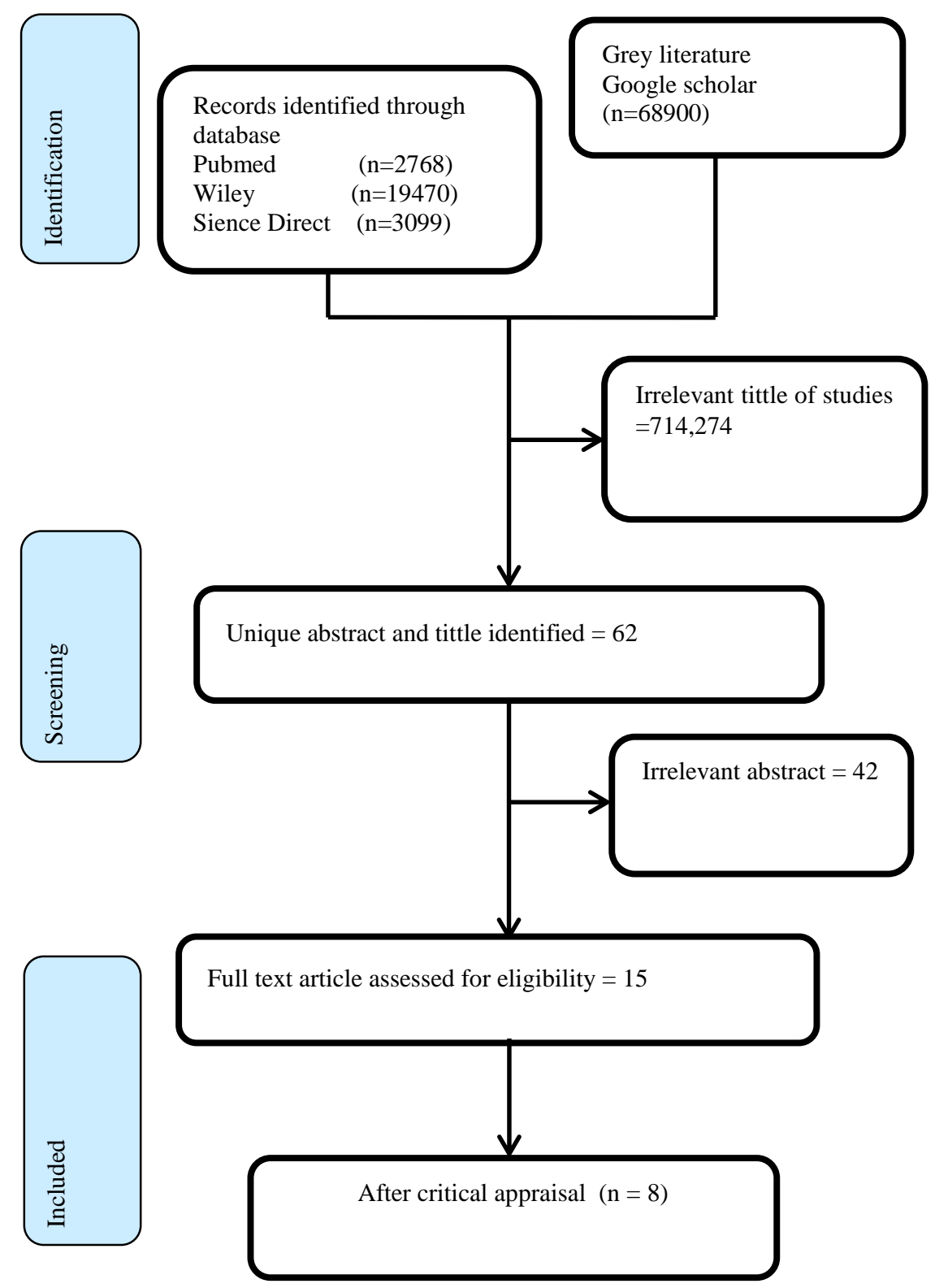

Fig. 1. Prism Flow Diagram

\section{d. Step 4 making data graphic}

The 8 articles that have already been obtained will be divided into the name of the writer, year of the origin country become one group further the purpose, method, population and results. The research will combine all the contents are grouping into theme and sub-theme 
Table 2. Charting Data

\begin{tabular}{|c|c|c|c|c|c|c|c|}
\hline No & $\begin{array}{c}\text { Title/ Author/ Year/ } \\
\text { Grade }\end{array}$ & Country & Aim & Type of Research & Data Collection & $\begin{array}{l}\text { Participants/ } \\
\text { Sample Size }\end{array}$ & Result \\
\hline 1 & $\begin{array}{l}\text { Every pregnant woman } \\
\text { needs a midwife. Maternal } \\
\text { experience HIV care for } \\
\text { pregnant women (Health et } \\
\text { al., 2016) }\end{array}$ & Northern Ireland & $\begin{array}{l}\text { To find out the } \\
\text { experiences of } \\
\text { pregnant women } \\
\text { with HIV positive } \\
\text { with midwife care }\end{array}$ & $\begin{array}{c}\text { Prospective } \\
\text { qualitative study }\end{array}$ & $\begin{array}{l}\text { Sociological } \\
\text { interpretation. } \\
\text { prospective repeat } \\
\text { interview }\end{array}$ & 10 participants & $\begin{array}{l}\text { HIV which is connected with the } \\
\text { stigma is increasing the experiences } \\
\text { pregnant woman infected HIV during } \\
\text { pregnancy and treatments. They get } \\
\text { new positive experiences about } \\
\text { impression, emphatic, and } \\
\text { understanding about their needs.. }\end{array}$ \\
\hline 2 & $\begin{array}{l}\text { Testing for HIV positive in } \\
\text { pregnant women is } \\
\text { phenomenological } \\
\text { experience of women } \\
\text { (Stallard et al., 2016b) }\end{array}$ & Africa & $\begin{array}{l}\text { to explore the } \\
\text { experience of HIV- } \\
\text { positive pregnant } \\
\text { women with } \\
\text { antenatal screening }\end{array}$ & $\begin{array}{l}\text { Qualitative approach } \\
\text { and } \\
\text { phenomenological }\end{array}$ & $\begin{array}{l}\text { Purposive sampling } \\
\text { strategy in-depth } \\
\text { semi-structured } \\
\text { interviews. }\end{array}$ & 13 participants & $\begin{array}{l}\text { The problems are shock, stigma, } \\
\text { secret, accept, and endurance } \\
\text { according to their feeling of isolating } \\
\text { from society. On the pregnant } \\
\text { woman which HIV positive culture } \\
\text { become problems so it occurs } \\
\text { abortion and suicide. }\end{array}$ \\
\hline 3 & $\begin{array}{c}\text { Maternity perception by } \\
\text { pregnant women living } \\
\text { with HIV (Huang et al., } \\
\text { n.d.) }\end{array}$ & Brazil & $\begin{array}{l}\text { Identify experiences } \\
\text { of pregnant women } \\
\text { with HIV with } \\
\text { expectations in } \\
\text { partners }\end{array}$ & $\begin{array}{l}\text { Descriptive design } \\
\text { and qualitative } \\
\text { approaches }\end{array}$ & $\begin{array}{l}\text { Semi-structured } \\
\text { interviews. }\end{array}$ & 10 participants & $\begin{array}{l}\text { Nurses are more responsive on the } \\
\text { treatments with integrity and } \\
\text { realizing the role while giving health } \\
\text { care and prevent possible } \\
\text { complication which affect the mother } \\
\text { and the fetus }\end{array}$ \\
\hline 4 & $\begin{array}{l}\text { The lived experiences of } \\
\text { rural women diagnosed } \\
\text { with the human } \\
\text { immunodeficiency virus in } \\
\text { the antenatal period } \\
\text { (Genevieve et al., 2018) }\end{array}$ & Africa & $\begin{array}{l}\text { Identify experiences } \\
\text { of HIV pregnant } \\
\text { women in the } \\
\text { antenatal period }\end{array}$ & $\begin{array}{l}\text { Qualitative approach } \\
\text { and } \\
\text { phenomenological }\end{array}$ & $\begin{array}{l}\text { Purposive sampling } \\
\text { and semi structured }\end{array}$ & 10 participants & $\begin{array}{l}\text { The four themes are obtained: the } \\
\text { reality hit, the hurtful lonely feeling, } \\
\text { a hope for tomorrow. Even though, } \\
\text { the participants have to receive bad } \\
\text { news about being diagnosed with } \\
\text { HIV and have lone life and a few } \\
\text { people support them, they still have } \\
\text { expectations to see the children's } \\
\text { future. }\end{array}$ \\
\hline 5 & $\begin{array}{l}\text { Pregnancy through the } \\
\text { Lens of Iranian Women } \\
\text { with HIV: A Qualitative } \\
\text { Study (Moghadam et al., } \\
\text { 2016) }\end{array}$ & Africa & $\begin{array}{l}\text { To explored of } \\
\text { pregnancy among } \\
\text { Iranian women with } \\
\text { HIV }\end{array}$ & Qualitative study & $\begin{array}{l}\text { Semi-structured, in- } \\
\text { depth interviews }\end{array}$ & 12 participants & $\begin{array}{l}\text { There is a feeling of anxiety in } \\
\text { pregnant women with transmission to } \\
\text { babies and their still to continue the } \\
\text { pregnancy. }\end{array}$ \\
\hline
\end{tabular}

A.A. Putri Melastini and Mufdlilah (The experience of pregnant women with HIV: scoping review) 


\begin{tabular}{|c|c|c|c|c|c|c|c|}
\hline 6 & $\begin{array}{l}\text { 'We have beaten HIV a bit': } \\
\text { A qualitative study of } \\
\text { experiences of peer support } \\
\text { during pregnancy with an } \\
\text { HIV Mentor Mother } \\
\text { project in England } \\
\text { (McLeish \& Redshaw, } \\
\text { 2016b) } \\
\end{array}$ & England & $\begin{array}{l}\text { To experiences of } \\
\text { women living with } \\
\text { HIV in the UK }\end{array}$ & $\begin{array}{c}\text { Qualitative } \\
\text { descriptive } \\
\text { phenomenology. }\end{array}$ & $\begin{array}{l}\text { Semi-structured, in- } \\
\text { depth interviews }\end{array}$ & 23 participants & $\begin{array}{c}\text { Pregnant women with HIV have fear, } \\
\text { lack of self-confidence and the } \\
\text { emergence of stigma gaps in } \\
\text { maternity care. }\end{array}$ \\
\hline 7 & $\begin{array}{l}\text { “"Telling my husband I } \\
\text { have HIV is too heavy to } \\
\text { come out of my mouth": } \\
\text { Pregnant women's } \\
\text { disclosure experiences and } \\
\text { support needs following } \\
\text { antenatal HIV testing in } \\
\text { eastern Uganda (Kotze et } \\
\text { al., 2016) }\end{array}$ & Uganda & $\begin{array}{c}\text { To explore the } \\
\text { experiences of } \\
\text { pregnant women } \\
\text { with HIV supported } \\
\text { HIV }\end{array}$ & $\begin{array}{l}\text { Qualitative } \\
\text { descriptive }\end{array}$ & In-depth interviews & 30 participants & $\begin{array}{l}\text { Their fears about the disclosure } \\
\text { influenced by gender intersection } \\
\text { norms, economic dependence, } \\
\text { woman's role as mother and early } \\
\text { age. Pregnant woman even they are } \\
\text { uninfected still need to alert because } \\
\text { they have a chance to get infected } \\
\text { with HIV since their partner } \\
\text { resistance doing test. }\end{array}$ \\
\hline 8 & $\begin{array}{l}\text { The lived experience of } \\
\text { pregnancy among HIV- } \\
\text { positive refugee women a } \\
\text { qualitative study (Chulach } \\
\& \text { GagnonHolmes, 2016) }\end{array}$ & Canada & $\begin{array}{l}\text { To describe the } \\
\text { experiences of HIV } \\
\text { positive pregnant } \\
\text { women }\end{array}$ & Qualitative research & $\begin{array}{l}\text { Interviews and } \\
\text { focus group } \\
\text { discussions }\end{array}$ & 4 participants & $\begin{array}{l}\text { The four themes are obtained: the } \\
\text { reality hit, the hurtful lonely feeling, } \\
\text { a hope for tomorrow. Even though, } \\
\text { the participants have to receive bad } \\
\text { news about being diagnosed with } \\
\text { HIV and have lone life and a few } \\
\text { people support them, they still have } \\
\text { expectations to see the children's } \\
\text { future. }\end{array}$ \\
\hline
\end{tabular}

A.A. Putri Melastini and Mufdlilah (The experience of pregnant women with HIV: scoping review) 


\section{e. Step 5 Arrange and Report the results}

The researcher will conduct 5 steps with several steps namely grouping 8 articles base on the method, country and grade after that take the theme and sub-theme.

\section{Result}

A. The characteristic of articles

1) Research design

Based on research design, there were 8 articles used qualitative method i.e. 3 articles used in deep interview and 5 articles used phenomenology

Fig. 2. Characteristics of the design and research approach

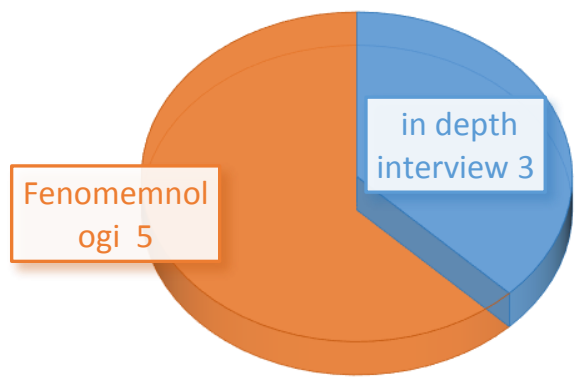

2) Based on the country

Out of 8 articles 4 are from development countries: Africa and Brazil. 1 is from advanced country: North Ireland, England and 1 is from underdeveloped country: East Africa poor country.

Fig. 3. Country Characteristics

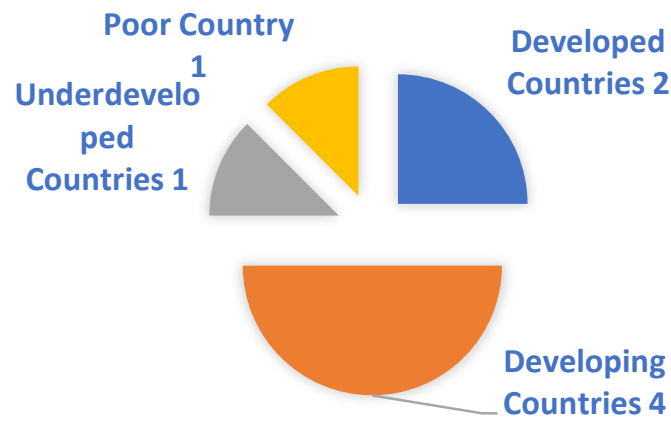

3) Based on critical appraisal grade (Hawker)

The articles are chosen based on the quality all the articles get the grade.

Fig. 4. Characteristics of Grade Critical Appraisal (Hawker)

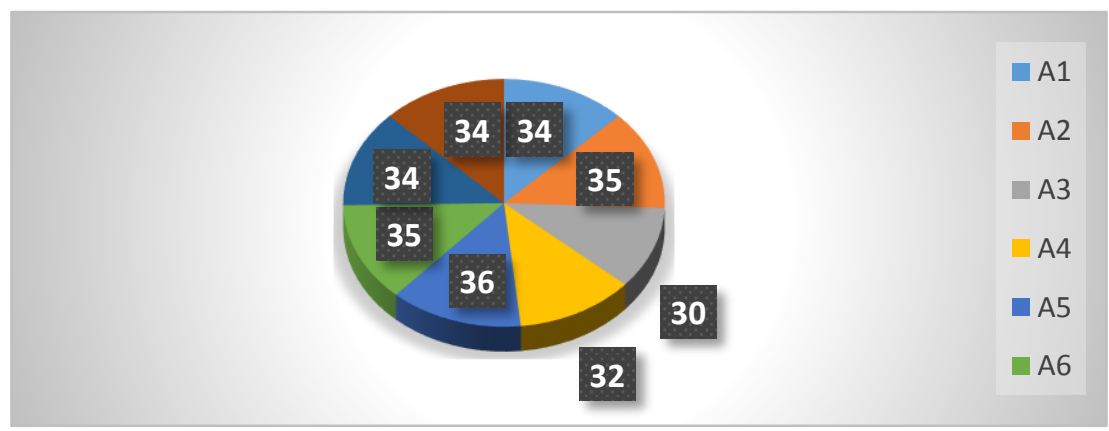


B. Mapping

Mapping helps the author to be able to group the findings of the problems to be studied and have been given a code that refers to charting data:

Table 3. Maping of pregnant women with HIV

\begin{tabular}{cc}
\hline Tema & Sub tema \\
\hline Psychology & Feeling anxious, worries and fears about the situation ${ }^{1378}$ \\
Coping Strategy: & Self-closing and rejecting with the result of suicide ${ }^{2468}$ \\
& ${\text { Pray and belief }{ }^{4567}}^{248}$ \\
& Isolation and treatment $^{248}$ \\
& Self-acceptance ${ }^{234}$ \\
Positive side & ${ }^{58}$ \\
The Role of Health Workers & Providing Good Quality $^{14}$ \\
& Bad Service $^{1678}$ \\
\hline
\end{tabular}

\section{Discussion}

Psychology changes during pregnancy are happen in each trimester both physically and mentally. Toward the pregnant woman with HIV encounter the higher escalation than non-infected woman (Maula, 2014). Most of the woman that HIV-Positive is still not reveals their condition (Rujumba et al., 2012). Husband's role is expected involve in constructive way for antenatal caring (Isni, 2016) and family will be a main source for long term support (Hill et al., 2018).

Feeling anxious and fears about the situation changes of feeling thinks about the health and visualize the baby born are the sign of mother (Chulach \& GagnonHolmes, 2016). Several women say they often felt anxious not understanding about HIV (Health et al., 2016). The feeling of fears happen during breastfeeding period will make it disturbed (Leyva-Mora et al., 2017). Woman will feel anxious when they have to honest with their partners because they will afraid the husband not fulfills the economic needs (Maula, 2014).

Self-closing and rejecting with the result of suicide when someone know they are positive with HIV there is a feeling to reject the truth along with the fears that there will be a stigma in the family and society for making the women to isolate themselves (Stallard et al., 2016a). Wasting their time for stabilize the emotional through isolation (Chulach, Gagnon, \& Holmes, 2016). There is a guilt when the trust from the partner are violated lead them to do abortion and suicide (Genevieve, 2018). The difficulty for opening themselves and accepting the situation make them more afraid when facing childbirth process (McLeish \& Redshaw, 2016).

Coping strategy which identification in more general socio-ecological frameworks on individual level and interpersonal (Moghadam et al., 2016). Women are frequently using religion (Kotze et al, 2013) and can develop positive coping strategy so can continue to withstand form every consequence of life (Ngocho et al., 2019).

The women believed about health, life and death depend on God's (North, 2017). Some women have religious beliefs which give them the meaning of problems occurs in their life (McLeish \& Redshaw, 2016b) and some say that religious belief can effect on the honesty of HIV (Rujumba et al., 2012). Gain the support from mother can spread positive effect and strengthen the feelings (Genevieve et al., 2018).

Self-isolation makes easier to accept and protect themselves (Stallard et al., 2016). The knowledge make the woman obeys for treatments to prevent the infection to the baby with appropriate medical prescription (Chulach et al., 2016). The treatment using ART give a hope that the mother will not transmittal virus to the baby and make sure the baby safe so they have a spirit following the program PMTCT (Genevieve, 2018).

The effort to solve the problems in accepting the pregnancy helps with (Ross et al., 2018) supports from medicals team which sanction them to get personal resilience to overcome HIV (Rujumba et al., 2017). When woman compare their illness with HIV make them hoping the better things and believe with God decisions (Genevieve, 2018). Positive side is the quality of sleeping while pregnant make woman knows themselves better (Chulach et al., 2016). 
Nurse can be an integral part of assessing knowledge and providing further education. So that, nurse can helps in management HIV treatment and discuss how to promote their general health. Mother who infected by HIV which get supports from medical staffs have chance 17 times for behave better on preventing HIV to the baby than mother who not receive any support (Isni, 2016).

Providing good quality from medical staffs can examine the comfort environment and respects while asking and telling the story of HIV experienced by some pregnant woman with giving best services that ensures the safety of mother and her baby. Positive relation with medical staffs' direct interaction can decrease and ease the problem (Health et al., 2016).

Providing Bad Service like the deficient of time when one of the women is asking questions and the medical staffs are not focus with the problems and the treatments Getting different information during the visit of topologist and doctor make the woman loses their trust. The lack of counseling time and some medical staffs reject to reach them make the patient feel sad and the woman loses their hopes and not continuing their treatments. Several women want the staff to support, help, and ensure their husband also get the test (Rujumba et al., 2012).

\section{Conclusion}

The scoping review of this research has been focused on the experience of pregnant women with HIV and the factor found that the psychology, coping strategy and the role of health workers as theme of scoping review. The scoping result obtained many participants stating that they get less comfortable behavior, not obtaining sufficient attention until violence in the household 


\section{References}

Abtew, Awoke, \& Asrat. (2016). Knowledge of pregnant women on mother-to-child transmission of HIV, its prevention, and associated factors in Assosa town, northwest Ethiopia. HIV/AIDS Research and Palliative Care, 8, 101-107. https://doi.org/10.2147/HIV.S100301

Arksey, \& O’Malley. (2019). Scoping studies: Towards a methodological framework. 8(1), 19-32.

Ashaba, Kaida, Burns, O’Neil, Dunkley, Psaros, \& Matthews. (2017). Understanding coping strategies during pregnancy and the postpartum period: A qualitative study of women living with HIV in rural Uganda. BMC Pregnancy and Childbirth. 17(1), 1-10. https://doi.org/10.1186/s12884-017-1321-9

Bettany-Saltikov. (n.d.). How to Do a Systematic Literature Review in Nursing: A Step-By-Step Guide. 2020. Two Penn Plaza New York, Ny 1012-2289.USA

Chulach, \& GagnonHolmes. (2016). The lived experience of pregnancy among HIV-positive refugee women a qualitative study. Advances in Nursing Science. 39(2), 130-149. https://doi.org/10.1097/ANS.0000000000000117

Fasoulakis. (2017). The social stigma of HIV-AIDS : society 's role.

Fermin. (2012). HIV and AIDS. In Scientist. In 12.

Genevieve. (2018). The lived experiences of rural women diagnosed with the human immunodeficiency virus in the antenatal period. 14(1), 1-4. https://guides.lib.vt.edu/researchmethods/design-method

Hawker, S., Payne, S., Kerr, C., Hardey, M., \& Powell, J. (2002). Appraising the evidence: Reviewing disparate data systematically. Qualitative Health Research, 12(9), 1284-1299. https://doi.org/10.1177/1049732302238251

Health, Alderdice, \& Psychologylohan. (2016). Kelly, C., Nurse, R. G. N. L., Every pregnant woman needs a midwife The experiences of HIV affected women in maternity care. 28(2), 132-138. https://doi.org/10.1016/j.midw.2011.12.003

Hidayanti. (2016). Women's Coping Stress Strategy With HIV / AIDS. Sawwa Jurnal Studi Gender, 9(1), 89-106.

Hill, Maman, Groves, \& Moodley. (2018). Social support among HIV-positive and HIV-negative adolescents in Umlazi, South Africa: changes in family and partner relationships during pregnancy and the postpartum period. BMC Pregnancy and Childbirth, 15(1), 1-9. https://doi.org/10.1186/s12884-015-0542-z

Holland, \& Roger, W. (2021). Writing for Publication in Nursing and Healthcare: Getting it Right.

Huang, H. Y., Tsai, W, C., Chou, W, Y., \& Hung, Y, C. (2017). Quality of life of breast and cervical cancer survivors. BMC Womens Health. 17. doi: 10.1186/s12905-017-0387-x

Huang, Li, Shih, Lin, \& Kang. (n.d.). Mother-to-child transmission of HIV: An 11-year experience in a single center and HIV prevention effectiveness in Taiwan. Journal of the Formosan Medical Association. 2019, 118(8), 1211-1217. https://doi.org/10.1016/j.jfma.2019.05.001

Isni. (2016). Family support, support from health workers, and the behavior of HIV mothers in preventing HIV / AIDS transmission to babies. 11(2), 95. https://doi.org/10.15294/kemas.v11i2.4014 
Kotze, Visser, Makin, Sikkema, \& Forsyth. (2016). The coping strategies used over a two-year period by HIV-positive women who had been diagnosed during pregnancy. AIDS Care Psychological and Socio-Medical Aspects of AIDS/HIV. 25(6), 695-701. https://doi.org/10.1080/09540121.2013.772277

Leyva-Mora, Piscoya-Angeles, \& Evidence., E. E. of P. in W. L. W. H. A. M.-S. of Q. (2017). Journal of the Association of Nurses in AIDS Care. 28(4), 587-602. https://doi.org/10.1016/j.jana.2017.04.002

Maula. (2014). Physical and Psychological Picture of Mother with HIV / AIDS While Pregnant in Kendal Regency. In II PPNI (pp. 262-269).

McLeish, J., \& Redshaw, M. (2016a). "We have beaten HIV a bit": A qualitative study of experiences of peer support during pregnancy with an HIV Mentor Mother project in England. BMJ Open, 6(6), 1-9. https://doi.org/10.1136/bmjopen-2016-011499

Moghadam, Khalajinia, Nasrabadi, Mohraz, \& Gharacheh. (2016). Pregnancy through the Lens of Iranian Women with HIV. Journal of the International Association of Providers of AIDS Care, 15(2), 148-152. https://doi.org/10.1177/2325957415593636

Ngocho, Watt, Minja, Knettel, Mmbaga, Williams, \& Sorsdahl. (2019). Depression and anxiety among pregnant women living with HIV in Kilimanjaro region, Tanzania. 14(10), 1-15. https://doi.org/10.1371/journal.pone.0224515

North. (2017). Communities at the heart? Urban Renaissance? https://doi.org/10.2307/j.ctt1t898kc.12

Ross, Stidham, Drew, \& Creswell. (2018). The Effect of Telephone Support on Depressive Symptoms Among HIV-Infected Pregnant Women in Thailand : An Embedded Mixed Methods Study. Journal of the Association of Nurses in AIDS Care, 24(5), 13-24. https://doi.org/10.1016/j.jana.2012.08.005

Rujumba, Neema, Byamugisha, Tylleskär, Tumwine, \& Heggenhougen. (2017). "Telling my husband I have HIV is too heavy to come out of my mouth": Pregnant women's disclosure experiences and support needs following antenatal HIV testing in eastern Uganda. Journal of the International AIDS Society, 15(2), 1-10. https://doi.org/10.7448/IAS.15.2.17429

Stallard, Christine, \& Tina. (2016). Testing HIV positive in pregnancy: A phenomenological study of women 's experiences. Midwifery. 35, 31-38. https://doi.org/10.1016/j.midw.2016.02.008

WHO. (2020). Training course and other tools. https://www.who.int/childgrowth/training/en/ 